\title{
Facebook Loves: Depression, Psychosis and Online Romance, Report of Three Cases
}

\author{
Kemal Sayar ${ }^{1}$, Zeynep Senkal ${ }^{1}$
}

\section{ÖZET:}

Facebook aşkları: Depresyon, psikoz ve çevrim-içi romantizm

Bu yazı internetin sosyal paylașım ag̃larının ve çevrimiçi ilişkilerin kendimizi tanımlama biçimlerimizi, gerçeklig̃e ve ruh sag̃lıg̃ına bakış açılarımızı nasıl etkiledig̃ini araștırmaktadır. Yazarlar bilgisayar temelli iletişimin modernliḡin ayrılmaz bir vasfı haline gelen zaman-mekan sürekliliḡini en iyi șekilde temsil ettiḡini düșünmektedir. İnternet mekanlarının dinamik oluşumu, kişiler arası etkileşimi ve iletişimi yeni biçimlerde etkilemekte ve zaman-mekan sürekliliḡinde gözle görülür bir deg̃işim meydana getirmektedir. Bu deg̃işim, zamanın geride bırakıldıg̃ı siber alanın sanal dünyasında, yeni bir kişiler arası ilișki duygusunu yaratmaktadır. Geçmişte yüz yüze yürütülen ve kurulan ilișkilerin yerini, artık sosyal teknolojinin ürettig̃i yeni bir ilişki tarzı almaktadır. Bu makalede internet kullanımının yakınlık ilişkilerimizi ve özelde romantik ilişkilerimizi nasıl dönüștürdüg̃ü ve bunun ruh sag̃lı̃̃ına etkilerini tartışıyoruz. Sosyal paylaşım ag̃ları üzerinden giderek daha fazla insan romantik ilișki kurmaktadır. Bu ag̃lar arasında Facebook, ortak ilgi alanları olan insanları bir araya getiren bir medya ortamı olarak dikkat çekmektedir. Yazarlar psikiyatrik yardım isteyen üç olgu üzerinden sosyal paylaşım ag̃larının ruh sag̃lıg̃ına etkisini tartışmaktadır. Facebook içinde romantik beklentilerine cevap alamadıg̃ı için depresif psikoz, halüsinasyon, insomni ve dig̃er stres verici yașantılar yaşayan üç olgu tartışılmaktadır. Sanal ortamda sevgi açlı̃̃ı ve duygusal boșlug̃u doyurma gayretinin, gerçek dünyada bir karşılık bulamadıg̃ı olgularda ortaya çıkan ruhsal sorunlar tartışılmaktadır. Sundug̃umuz üç olguyla birlikte, bu yeni medya biçimlerinin psikopatolojiye tesir eden iletişim örgüleri çıkabileceg̃ini tartışmış oluyoruz.

Anahtar sözcükler: internet, self, sosyal medya, facebook, psikopatoloji

Journal of Mood Disorders 2014;4(1):26-33

\section{ABSTRACT:}

Facebook loves: depression, psychosis and online romance, report of three cases

This paper explores the impacts of the Internet, social networking sites, and online-relationships on selfdefinition, perspectives of reality, and mental health in contemporary times. The authors explain how computermediated communication seems to be the culmination of the time-space continuum endemic to modernity. The dynamic formation of the Internet sites has provided new ways of interpersonal interaction and communication that have created a highly impactful shift on the time-space continuum. This shift appears to transcend time as it creates a new sense of interpersonal connection in the virtual realm of cyberspace. Relationships that were previously established and sustained primarily through face-to-face interaction have come to be complemented by a social technology that is creating a new genre of interpersonal relationships. The article highlights contradictory views about how the use of the Internet affects intimacy, expands to another area, namely, romantic relationships. By use of social network sites, an increasing number of people are found to have online romantic relationships. Among these Facebook is a medium that brings people together who have shared interests. Three cases describe experiences of persons seeking psychiatric assistance who experienced depressive psychosis, hallucinations, insomnia and other stressful and disorienting experiences after Facebook relationships formed in virtual communities. Attempts to resolve discrepancies related to the emotional void resulting from differences between online virtual satisfaction of needs for love and actual offline absence of the so-called loved one are explored. We are providing three cases where psychopathology might be fostered with these new forms of media.

Key words: internet, self, social network, facebook, psychopathology

Journal of Mood Disorders 2014;4(1):26-33

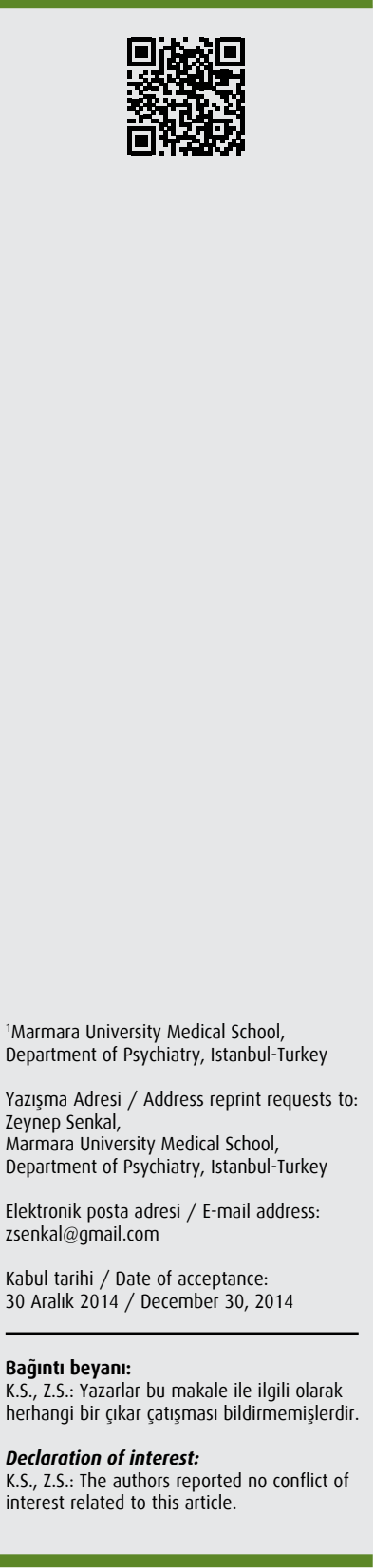




\section{INTRODUCTION}

Enhancement of the internet technology has led to important social and psychological changes especially after the development of web 2.0. These changes can generally be summarized in four different ways: The collapse of space into a virtual presence, the creation of an "extended present" (1), the shift of the internet usage from information gathering to communicating, and the formation of "virtual selves" and the "virtual relationships" $(2,3)$ as an inescapable result of this communication.

By the unique capability of the Internet that allows someone "to be" at a place where the body is absent (4), this "disembodying technology" allows the person to neglect the very physical way of being, which is absolutely the core part of the persona. Such a release from the physical boundaries of the self overvalues the mind; as a postmodern "Mind or Body Dichotomy". One perspective views such detachment of the body from the self as a positive development by which one can be freed. One can spend less time and energy while interacting with others or searching for various kinds of knowledge. The "detached" method seems much easier in contrast to the face-to face interactions and methods of physical performance in searching for knowledge. Since all barriers of the physical self are removed by the use of the Internet, it is also possible to meet the maximum number of people with the least amount of energy consumption and cost (2) which are not possible in real world (5).

This "virtual dissociation" of the body from the self is the first, but not the least of the important changes: The new "online" version of the self has gained an extreme flexibility on creating its own narrative stories. Since creating narratives is one of the most important functions of the self that cannot be precluded, and the internet, especially social networks empowers individuals to re-create an imaginary world where an incredibly high degree of personal freedom is presented with minimum necessity to deal with reality, the "virtual self" became the most elastic self of all times. Thus one has an incredibly high degree of personal freedom to selectively highlight his or her real or imaginary personal features, or detach and remove other aspects of their "online identity", and to construct an alternative "virtual self" easily (6). Therefore, efforts to create "offline reality" may cause a kind of "depersonalization" risk to emerge (7): the presentation of the online self and the online life begin to differentiate from the person's real-life presence. An "incongruence gap", which can be demoralizing and traumatic for the real-life person starts developing. Instead of enabling the individual to digest and filter his or her experiences and then incorporate them for growth or change, the unanticipated results are increasing detachment and depersonalization.

This new self, which has a high potential to detach from the realities of one's personal life, can also be a strong agent for impression management; especially when the person has dominant hysteric or narcissistic motivations. The personal wish of "becoming known by others" can turn into narcissistic pleasure seeking and an emerging rootless self- esteem (8) and the virtual self turns into a "miniature celebrity" via the net $(9,10)$. Getting in touch with many others may become an advantage for gaining additional information as the social network expands despite the weakly bonded relationships (11). One does not need to make great efforts to maintain the relationships (12) while engaging in minimal personal interaction necessary for adequately relating. Unfortunately, building effortless and quick relationship cause one's virtual relations to be weak (7) and affect the understanding of "life"; which may cause worse consequences.

Such a shift in the form of "being" means slipping from more reciprocal relationships to more self-centered ones: the virtual being searches for the nurturing online relations which eventually and exactly prove the uniqueness of one. Thus, the kind of "intimacy" that one tries to experience online changes from the intimacy that we have known in face-to-face relations: the feelings of loneliness and grief of the alienated persona can easily force the "voluntary" individual in discussing his or her "private world" via the net $(9,13)$. The formerly private, hidden, introverted and quiet world is published more easily and becomes more visible and loud in the public world $(14,15)$. Exchanging stories becomes easier where people are partially or fully anonymous (16) and searching for guidance of virtual others is more pleasurable (2). Unfortunately such a shift in the relationships means that self-disclosure is becoming less intimate, with the aim of expressing, depicting and valuing the self -the self which is his or her only and unique hero- and electronic gadgets become places where people use more for themselves 
(15). It is this new form of intimacy, which McKenna and colleagues thought as an individual exercise to construct the self; the virtual one (17).

The narrated online self, with the most possible form of anonymous being, who searches the online environment for his or her highest self-centered motives happens to survive in a virtual place; where the reality of the real life and the spuriousness of the virtual life are increasingly differentiated from each other (4). The use of voices, gestures, videos and photos has enabled Internet users to create their psychic reality on the Net, which is constructed and supported by its further use again and again (2).

The intimacy of online relationships; not only of the online friendships but the more "intimate" ones; also of the online romantic relationships; is then in great danger. (2). Because the real intimacy is highly associated with the feeling of "trust", and since the virtual selves have a high freedom to depict their physical features, character, interests, age, occupation and even gender with respect to their personal fantasy (18), building and maintaining healthy-trusting relationships become harder on the net. This means that there is a very high potential for the collapse of relationships: the idealization of the other person will be faster and easier (13) than maintaining that relationship.

One of the ways in which the virtual relationships collapse may occur when the person desires extending the virtual relationships to real ones. Because bodily interactions are very important for all intimate relationships including the friendship and especially the romantic love, people may have a high tendency to convert those online relationships to offline (4). In this pure form of intimacy where the body is welcomed and not neglected, the physical interactions will be nurturing the people and will enable to feel a more full range of intimacy (19). On the other hand without having real physical contact with the other, such a learning process can never be successful on the Internet. Therefore, "online intimacy" can be no more than the joy and blankness of its reality (18).

The destruction of the relationship, with the loss of the idealized "virtual other" mostly occurs when one of the people invites other to transform the online relation to offline. Idealized other may directly refuse to meet, or even hesitate to keep the online relationship because he or she is not ready, or his or her depicted virtual self is highly inconsistent with the real self.

Because of the fact that those turn to online relationships and prefer to search intimacy via the net are mostly the individuals who have more struggles with intimacy in their face-to-face relations (20), experiencing the virtual loss and virtual abandonment may be more suffering for them. The pain of the virtual self might be caused by two different reasons: the loss of fantasized intimacy and the loss of another who is needed to be identified with the self (21). Latter, the loss of chance for intimate identification is directly related to self, whereas the prior loss is relatively about the loss of object. Even these two factors are still present in the offline break ups, face-to-face interaction becomes a preventive mechanism from the possibility of such losses when compared to virtual ones. Besides, one should not forget the fact that virtual sufferers could probably not develop the coping skills to overcome such problems when compared to others.

Below we are providing three case examples where psychopathology might be fostered with these new forms of media.

\section{CASES \\ THE CASE OF G.}

G. is a 40 year-old single woman who has suffered numerous depressive episodes since the age 30 . She lives on the southern coast of Turkey on her own. She worked at a real estate agency as a trainer and is currently unemployed. She came to the private practice of the first author questioning her relationship of 7 months with another woman, with whom she had broken up in August 2010. Her mother encouraged her to see a psychiatrist. G believed she was receiving messages on Facebook from her ex-girlfriend and she also believed supernatural beings were visiting her. G. had fantasized about being loved by her Facebook friend and thought that the Sufi messages sent by her actually signified her love. She and her Facebook friend were having an intense exchange of quotations from Sufi saints. They wrote to each other about the merits of divine love. Her friend had never revealed any sexual interest but G. was taking her Sufi quotations as disguised messages of such an interest. This kind of Facebook interaction continued for three months 
and finally G. revealed her feelings. Her friend immediately left her and did not respond to her further messages. G. was very disappointed but she believed that her friend was still in her Facebook account with a different name. She continued to send her very symbolic messages pertaining to their love.

"They all left me because they just could not accept the reality of being in a relationship with a woman. I think my borderline personality caused my interest in women. My partners have always been a symbol of authority and power. Should I give in? Should I be a part of this game? “

G. wasfeelingindecisive, cursing God and experiencing anger turned inward. 2 years ago she got intimate with her psychiatrist. When she denied her homosexuality, she got involved in unsatisfactory relationships with men. Her friend had left her 2 months ago and she was suffering enormously. The relationship had the dynamics of a mother-infant relationship. "She came back to my life in different forms and with different names. My feelings change constantly. She is following everything about me and she is sending me messages under different names. Finally I told her that I was aware of her game. She is a very strong shaman. When I went back home from Istanbul, the djinns attacked me, I wrote to her immediately, asking why she was testing me in this way, why she was making me go through hell? Friendly souls and angels started showing up in her form. She made me go through this to make me experience unconditional love. Whenever I log on to Facebook, I sense the messages, even before they even appear in my mailbox. "Am I giving up something very precious? You are right, I gave you all those roles, I made you a lover, I made you a mother..."

Believing that her ex-lover was sending her messages, G. interpreted them in a way that made her feel good.

"I wish I was not aware of anything. I do not want to be a part of this game. I do not want to be a part of anything that is happening in this world or in the other world. They are following me because they want to protect me. I do not know the rules of this game. I do not know my feelings. Was I ever in love with her? Everything in this universe is a whole and there are friendly souls. They are supporting me constantly. She keeps on sending me love messages."

At the end of the second session, G. was diagnosed with depressive psychosis and was prescribed an antidepressant and an antipsychotic. She did not want to use the antipsychotic and looked very confused. "I just cannot figure what I am going through. This experience is beyond me. I have lost a friendship and this really bothers me. My self-confidence hit rock bottom. I was finally myself when I was with her. I need to be loved by somebody." In December, 2010, G. moved to Istanbul. Her psychotic thoughts had vanished. She did not use the antipsychotic at all. Instead she used antidepressants and her mood seemed to have improved. Her crying episodes had decreased. "My relationship with my ex was a continuation of something I had never experienced in my life, maternal love," G. said. She no longer believed she had ever received those messages from her supposed ex-lover. "My thoughts have changed a lot. For a while I thought she wanted to kill me. Trying to fulfill my spiritual needs, I got carried away by people who claimed to have spiritual power. My ex told me she was a soul shaman. I want to be an individual. I want to defeat all my fears. I had enough of Facebook. Hell with it!"

I received a phone call from G.'s sister on March 5, 2011. "G. thinks she is God. She claims she is getting intimate with the angels. She is telling us that she created us. She claims she wrote the Qur'an. She is extremely active, energetic, talkative, alert and hostile. She doesn't sleep much and she is not taking her medications. She comes up with her own meanings for the words. She says she can make miracles happen". She was hospitalized in a mental hospital.

\section{THE CASE OF B.}

On September 2010 B. came to the private practice of the first author, with an apparent gait disturbance and as if she was having a real difficulty in talking. She was stuttering and she talked as if she was suffering from a neurological disorder.She also complained about auditory hallucinations, insomnia, seizures, weakness, syncope, dysphonia, and occasional disorientation in time and place for almost two months. She is a 35 yearold, single, elementary school teacher who lives alone in Istanbul. She is from a small town located on the Aegean side of Turkey where her family still resides.

She had her first psychogenic non-epileptic seizure on September 2, 2010 which she describes saying, "My brain was exhausted. I thought I was having a brain stroke. I started tapping my feet on the ground involuntarily and I had no control over my body and my speech started 
bouncing on every word."

B. spent majority of her free time on social networking sites, and she met a man on Facebook whom she believed to be her soul mate. The man introduced himself as an anarcho-Sufi and he contacted her only on Facebook. After 3 months of talking online for long nights, she asked the man out on a date and never received an answer. Disappointed by his absence in a real face to face interaction, she sublimated her agony and said "This is making love over Facebook. This is beyond anything human, what is going to happen to my love? This question drives me mad. He says love is Allah. I have fallen in love, I have become love myself, I got pregnant from love and I gave birth to love.'

In the interviews she preferred to talk in a very poetic, symbolic fashion. She said that she is a bastard of love. "I feel exhausted when I talk, walk and I am constantly thirsty. No matter how much water I drink, it is never enough. It feels like nothing in this world will ever make me feel okay. I haven't been sleeping at nights and when I do it is never relaxing. I start crying when I feel desperate which is pretty much the whole time. I have been living in Istanbul by myself for 6 years and now my family is here because I am not able to take care of myself. They keep telling me to relax and to calm down but it makes me feel worse, I feel under pressure...I have no patience for anything and I was crazy, stubborn and angry at people. On September 2nd, I came home from school. I had not been sleeping for couple nights and I was feeling extremely tired. I fell asleep in the afternoon, I slept for four hours. The phone ringing woke me up and I was scared. My initial thought was that I must have slept for months or maybe years. What year is it? What is the date? Time has changed and whatever money I have is not going to be worth anything. Following this thought, I had my first seizure and since then I am afraid of being alone. I used to enjoy night-time. Welcoming the night and feeling it but now I am afraid of the nights, I am afraid of going to sleep." B is of course making reference to a Biblical story here, where Ashab- Kehf ( the seven sleepers) fell asleep in a cave and when they woke up, centuries had passed and their money was no longer valid.

In reply to a question regarding what she liked about the nights so much, she started talking about the man she met Facebook on June 6th, 2010 whom she described as anarcho-Sufi. “A. was someone who came upon my prayers. I fell in love, I was love, I gave birth to his love. I vanished, and then I was reborn. He told me that love is God and his love brought me closer to God, closer to infinity. It was the first time I fell in love and it was very special. After long nights of talking online, B. asked A. out but he never agreed. She insisted that they should meet in person but A. constantly refused to appear. He said that truly Sufi love is about not meeting each other. According to A. if they ever met, their Sufi love would perish and become something very mundane. B. was very disappointed with this, since she thought that she finally found the man of her life. He was able to understand her and they both had a Sufi view of the world.

At the end of the first session B. was prescribed an antidepressant for her depressive mood. After starting her medication, B.'s mood improved, she no longer had any seizures. She was well for a month. She started having seizures again the day she started school. She shared her condition with the school principaland her students. Her seizures started getting stronger and stronger every day. "I despise school. I hate my job. School is so much like the military and I don't find it sacred at all. This illness is my savior. Talking on Facebook was very therapeutic for me. Overall I feel lonely, Facebook made that feeling go away. It was my way of getting my thoughts and my feelings out. It was relaxing. A. is still inside me. If what happened between us was making love on Facebook, then what is going to happen to my love? This question drives me crazy. Forgetting A. means forgetting my belief in love. I have to be patient. I have to wait for him. If he really loved me, he will come back to me."

B. did not take her medication for a week. She started suffering from loss of appetite, tiredness, crying, vomiting, and dizziness. She woke up restless in the mornings and got tired very easily at school." I am tired of fighting with this illness. When I get ill, my family gets ill too and I want them out of my house. I want my life back. I cannot eat, I vomit everything I eat. Why am I so tired? I breathe quickly and I feel heartache. I feel confused. Nothing, no one is enough; I want to give birth to a new self. A. brought me closer to the idea of having a man in my life, someone I can share my bed with, someone I can get close to, someone I can have kids with. I thought that someone was A. then I realized that he is not coming back but I still need a man."

It was recommended that B take her antidepressants 
and small doses of anxiolytics were prescribed. On November 2011 B. was still suffering from pseudoseizures. Her longest seizure lasted for 4 hours following a 2-week-long seizure free period. "The more I try to control myself, the more I lose control. I have no tolerance for stress. When the seizure starts, I start moving like a robot. My problem-solving ability dropped to zero. My brain is tired. I don't want to try anymore; I want the medications to make me feel okay. Nothing ever goes right in my life so I would have been surprised if A. had not disappeared. It could have been the very first time something actually happened in my life."

On February 2011, B. was still on medication. She didn't have any major seizures for 6 weeks. Her stresstolerance was still low. She was having sleeping problems. Her appetite was poor and she was feeling tired most of the time. She commented about her love: "I have paid my dues in love but I don't regret it at all. I haven't forgotten him. He is still alive inside me. The minute I make a decision of forgetting him, I collapse. At times like these, I feel lonely, I feel like I am a bird with its wings cut off. A. and I had waited for each other for years, what we had was real. I don't use internet anymore, to me A. and internet were the same. I believe he also doesn't use Facebookbecause I am not on it anymore. I know he loved me deeply. A. is very much like me. He is dramatic and wants to feel life to the fullest. Our relationship was supernatural. He used to tell me that he came into my life because he saw my suffering, he saw what I was going through and he tried to comfort me, he tried to teach me but then one day he said that I would suffer even more if we met. I still have unanswered questions. It should not have ended this way."

\section{THE CASE OF S.}

S. is a 20 year-old girl who was suffering from depression with psychotic features when she first consulted to the first author in September, 2009. She was brought in by her family with the complaints of apocalyptic thoughts, living in a dream-like state, withdrawal and spending too much time with her computer. She was spendingnearly the entire day surfing on Facebook. She had graduated from a religious high school and then attended a two-year college for public relations. She fell in love with a heterodox Sufi master on Facebook. The man contacted her via sublime messages concerning Sufism. S. thought that she was the center of the universe for this Sufi master. She interpreted all of his vague messages concerning Sufism as his love towards her. When she finally visited him at a café, she had a terrible disappointment because the man told her that he had no interest in her at all and he just wanted to help her. Finally, she broke into a depression with psychotic features. In my initial interview, she told me that she expected impending doom, and everybody will be saved except her. "Something very bad will happen!” She constantly ruminated. She could not get to the point. She had thought blocks and could only speak in fragmented sentences. Her mother told me that she was very unhappy and that she used to surf a particular Sufi website, where she wrote obscure messages. She poured her soul out to a man there. She was attracted to his magnetism. But she could not get the response she wanted from him. She was torn off from this life as if she had entered into a new world. She told me that she had seen Malcolm X on the way. She started calling herself a Messiah. She received messages from TV." S. was very sure of the love of I. who happens to run a Facebook group conveying rather heterodox Sufi theology. He has fans and runs a cafe, where he meets with his disciples. He is older than S. and S. usually calls him 'Brother I' referring to his age and status. "If I do not say anything to Brother I, something bad will happen' she said. 'I think I am being manipulated by some higher powers. I am confused." She was sad and she seemed desperate. She was prescribed a regimen of an antidepressant and an antipsychotic for her. In the coming weeks she felt better but went on talking about Brother I. She thought that Brother I was in love with her but could not reveal this openly. So he used to send these symbolic messages to her, which was direct evidence of his love. Why would he have sent these messages if he was not in love? She urged her parents to visit him and talk about her love. She tried to convince her doctor that this was not an unrequited love. In one of her visits she told her doctor that she was frustrated with Brother I. since he was not responding to her e-mails anymore. When she met him at the cafe, he plainly told her that he had no interest in her and all he tried to do was to help her. As she was recovering from her psychosis, she remembered that she used to confuse other people with Brother I. While she was traveling on a boat, she thought Brother I had shown 
himself to her. This is a common Sufi theme. Sufi saints sometimes disguise themselves and reveal themselves only to those who's "heart's eyes" are open. She had a very attentive family and she followed her drug regimen carefully. After several months she was free of her erotomaniac delusion and was even joking about this. She told in one of our latest interviews, "I am not a Majnun anymore", giving herself the role of the male desert wanderer who seeks for his love Layla. She seems to be doing well now and she stays off Facebook.

\section{DISCUSSION}

As one can obviously see, all three people are feeling as if they are suffering from the lack of intimacy in their lives; either they cannot develop warm and intimate relationships with any other, or they cannot maintain those relationships that once they have had. Online communication via social networking sites may have been beneficial for these people and they have enabled them to build personal relations faster and easier at the very beginning of the survey. Thus, people who are discussed in our cases might have had a pseudo-self esteem at first (8) because of the increased social capital through the online communication (22). Having more self-disclosure on the net (23), these people might have

\section{References:}

1. Balbus ID. Mourning and Modernity. Essays in the Psychoanalysis of Contemporary Society. New York: Other Press, 2005.

2. Ben-Ze'Ev A. Love Online: Emotions on the Internet. Cambridge: Cambridge University Press, 2004.

3. Kraut R, Patterson M, Lundmark V, Kiesler S, Mukopahyay T, Scherlis W. Internet Paradox: A social technology that reduce social involvement and psychological well-being? American Psychologist. 1998;53:1017-31.

4. Illouz E. Cold Intimacies: The Making Of Emotional Capitalism. Cambridge: Polity Press, 2007.

5. Hamington M. Care. Ethics, Friendship and Facebook. (In: Wittkower DE, editor) Facebook and Philosophy. Chicago; Carus Publishing, 2010. p. 135-145.

6. Thalos M. Why I am not a Friend. (In: Wittkower DE, editor) Facebook and Philosphy. Chicago: Carus Publishing, 2010. p. 75-89

7. Bloor C. What Are Friends For? (In: Wittkower DE, editor) Facebook and Philosphy. Chicago: Carus Publishing, 2010. p. 147-157. felt that they have reduced the uncertainty in their relationships and finally acquired the "true, fulfilling intimacy". Unfortunately, these fantasized images of both self and the others are so vulnerable and they can easily be broken down when one wants to transmit the online relationship to the offline: That was the time when the idealized, intimate relations collapsed and these people developed psychopathologies.

One of the most important things about the cases is the fact that these online interactions took place in "online sufi communities". Because of the fact that sufism has a philosophical background which overvalue love, acceptance and appreciation of the others, it provides an appropriate context for these people who have a certain need for intimacy. Thus, people who are discussed in our cases might have felt themselves more welcome at first, and could have felt satisfaction through this kind of interaction. It should also be stated that the philosophical language of sufism involves metaphorical communication and the use of signs. Unfortunately in online communities, the facial cues of the other are absent and one can misinterpret the sufi symbols more easily. Thus, people who are discussed in these cases probably experienced sharp and intense feelings of sadness and guilt along with being rejected and having lost their very unique, special, intimate online relations.

8. Cuonzo M. Gossip and the Evolution of Facebook. (In: Wittkowe DE, editor) Facebook and Philosphy. Chicago: Carus Publishing, 2010. p. 173-180.

9. Deresiewicz W. Faux Friendship. The Chronicle Review. 2009;6:12 6.

10. Deresiewicz W. The End of Solitude. The Chronicle Review. 2009 Jan 30 .

11. Ellison N, Steinfield C, Lampe C. The Benefits of Facebook "Friends:" Social Capital and College Students' Use of Online Social Network Sites. Journal of Computer Mediated Communication 2007;4:1143-68.

12. Tedesco M. The Friendship That Makes No Demands. (In: Wittkower DE, editor) Facebook and Philosphy. Chicago: Carus Publishing, 2010. p. 123-134.

13. Wallace P. The Psychology of the Internet. Cambridge: Cambridge University Press, 1999.

14. Grimmelmann J. The Privacy Virus. (In: Wittkower DE, editor) Facebook and Philosophy. Chicago, Carus Publishing; 2010. p. 3-12. 
15. Bauman Z. Liquid Love: On the Frailty of Human Bonds. Cambridge: Polity Press, 2003.

16. Wang $\mathrm{H}, \mathrm{Lu} \mathrm{XA}$. Cyberdating: Misinformation and distrust in online interaction. Informing Science Journal. 2007;10:1-15.

17. McKenna KYA, Green AS, Gleason MEJ. Relationship formation on the internet. What's the big attraction? Journal of Social Issues. 2002;58:9-31.

18. Manen MV. The Pedagogy Of Momus Technologies: Facebook, Privacy, and Online Intimacy. Qualitative Health Search .2010;20:1023-32.

19. Cheshire WP. Facebook And The Fusiform Gyrus. Global Bioethics. 2009;25:139-144.
20. Scott VP, Motarella KG, Lavooy MJ. Does virtual intimacy exist? A brief exploration into reported levels of intimacy in online relationships. Cyberpsychology Behavior. 2006;9:759-61.

21. Helm BW. Love, friendship and the self. 2009; New York; Oxford Press.

22. Ellison N, Steinfield C, Lampe C, Vitak J. With a little help from my friends. How social network sites affect effect social capital processes. In: Papacharissi Z, editor. A Networked Self: Identity, Community, and Culture on Social Network Sites. Routledge, London; 2011.

23. Baym NK. Personal Connections in the Digital Age. Cambridge; Polity Press, 2010. 